\title{
INCORRIGIBLES AND INNOCENTS $\infty$
}





\section{INCORRIGIBLES AND INNOCENTS $\infty_{\infty}^{\infty}$}

Constructing Childhood and Citizenship in Progressive Era Comics

LARA SAguisag

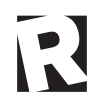

RUTGERS UNIVERSITY PRESS

NEW BRUNSWICK, CAMDEN, AND NEWARK, NEW JERSEY, AND LONDON 
Library of Congress Cataloging-in-Publication Data

Names: Saguisag, Lara, author.

Title: Incorrigibles and innocents : constructing childhood and citizenship in progressive era comics / Lara Saguisag.

Description: New Brunswick : Rutgers University Press, 2018. | Includes bibliographical references and index.

Identifiers: LCCN 2018003851| ISBN 9780813591773 (hardback)|ISBN 9780813591766 (paperback)

Subjects: LCSH: Comic books, strips, etc.-United States-History and criticism. | Children in literature. | Citizenship in literature. | Literature and society-United StatesHistory. | BISAC: SOCIAL SCIENCE / Popular Culture.| LITERARY CRITICISM / Comics \& Graphic Novels. | HISTORY / Social History. | PERFORMING ARTS / Film \& Video / History \& Criticism. | HISTORY / United States / 20th Century. | SOCIAL SCIENCE / Children's Studies. | SOCIAL SCIENCE / Gender Studies.

Classification: LCC PN6725 .S35 2018 | DDC 741.5/973—dc23 LC record available at https://lccn.loc.gov/2018003851

A British Cataloging-in-Publication record for this book is available from the British Library.

Copyright (@) 2019 by Lara Saguisag

All rights reserved

No part of this book may be reproduced or utilized in any form or by any means, electronic or mechanical, or by any information storage and retrieval system, without written permission from the publisher. Please contact Rutgers University Press, 106 Somerset Street, New Brunswick, N.J. 08901. The only exception to this prohibition is "fair use" as defined by U.S. copyright law.

(ळ) The paper used in this publication meets the requirements of the American National Standard for Information Sciences-Permanence of Paper for Printed Library Materials, ANSI Z39.48-1992.

www.rutgersuniversitypress.org

Manufactured in the United States of America 
For my father, Rene, and in memory of my mother, Dulce 
